\title{
Municipal solid waste management decision-making during COVID-19 pandemic: a comparison between Brazil and Portugal
}

\author{
Decisões gerenciais no gerenciamento de resíduos sólidos durante a pandemia de COVID-19: uma \\ comparação entre Brasil e Portugal
}

Decisiones gerenciales en la gestión de residuos sólidos municipales durante la pandemia COVID19: una comparación entre Brasil y Portugal

Received: 12/13/2021 | Reviewed: 12/21/2021 | Accept: 12/24/2021| Published: 01/04/2022

Ana Teresa Rodrigues de Sousa ORCID: https://orcid.org/0000-0001-9175-7639

Ezequiel Dias Foundation, Brazil

E-mail: anateresars.25@gmail.com

Susana Paixão

ORCID: https://orcid.org/0000-0002-4548-1894

Polytechnic Institute of Coimbra, Portugal E-mail: supaixao@hotmail.com

Marcos Paulo Gomes Mol

ORCID: https://orcid.org/0000-0002-2568-3579

Ezequiel Dias Foundation, Brazil

E-mail: anateresars.25@gmail.com

\begin{abstract}
Decisions related to waste management were affected to contain the advance of the new coronavirus pandemic. Different measures have been adopted between countries around the world. This study aims to assess changes in decision-making on solid waste management in Brazil and Portugal during the COVID-19 pandemic, considering the socioeconomic differences and the context of waste management in each country before the health crisis. A literature review was carried out on scientific bases, PubMed, Google Scholar and Web of Science. Differences were noted in decisions and guidelines for good practices in waste management, with measures being observed in a decentralized manner in Brazil, differently from what was observed in Portugal. In this way, the understanding of urban waste management during the COVID-19 pandemic in Brazil becomes complex, in addition to the territorial extension and the diverse social composition, due to the decentralization of decision-making, while Portugal centralizes decisions related to waste management and has a smaller population and territorial extension.
\end{abstract}

Keywords: Waste management; Municipal solid waste; COVID-19; Brazil; Portugal.

\section{Resumo}

As decisões relacionadas ao gerenciamento de resíduos foram afetadas para conter o avanço da pandemia do novo coronavírus. Diferentes medidas têm sido adotadas entre países em todo o mundo. O presente estudo visa avaliar as mudanças na tomada de decisão sobre a gestão de resíduos sólidos no Brasil e em Portugal durante a pandemia COVID19, considerando as diferenças socioeconômicas e o contexto da gestão de resíduos em cada país antes da crise de saúde. Foi realizada uma revisão de literatura em bases científicas, PubMed, Google Scholar e Web of Science. Notaram-se diferenças nas decisões e orientações de boas práticas no gerenciamento de resíduos, sendo medidas observadas de forma descentralizada no Brasil, diferentemente do observado em Portugal. Desta forma, o entendimento da gestão de resíduos urbanos durante a pandemia COVID-19 no Brasil torna-se complexo, para além da extensão territorial e da diversa composição social, devido à descentralização da tomada de decisões, enquanto Portugal centraliza as decisões relacionadas com a gestão de resíduos e tem menor população e extensão territorial.

Palavras-chave: Gerenciamento de resíduos sólidos; Resíduos sólidos municipais; COVID-19; Brasil; Portugal.

\section{Resumen}

Las decisiones relacionadas con la gestión de residuos se vieron afectadas para contener el avance de la nueva pandemia de coronavirus. Se han adoptado diferentes medidas entre países de todo el mundo. Este estudio tiene como objetivo evaluar los cambios en la toma de decisiones sobre la gestión de residuos sólidos en Brasil y Portugal durante la pandemia COVID-19, considerando las diferencias socioeconómicas y el contexto de la gestión de residuos en cada país antes de la crisis sanitaria. Se realizó una revisión de la literatura sobre bases científicas, PubMed, Google Scholar 
y Web of Science. Se observaron diferencias en las decisiones y directrices de buenas prácticas en la gestión de residuos, observándose las medidas de manera descentralizada en Brasil, a diferencia de lo observado en Portugal. De esta manera, la comprensión de la gestión de residuos municipales durante la pandemia COVID-19 en Brasil se vuelve compleja, además de la extensión territorial y la diversa composición social, debido a la descentralización de la toma de decisiones, mientras que Portugal centraliza las decisiones relacionadas con la gestión de residuos y tiene una menor extensión poblacional y territorial.

Palabras clave: Gestión de residuos sólidos; Residuos sólidos municipales; COVID-19; Brasil; Portugal.

\section{Introduction}

Human activities were changed by the measures to reduce the spread of the new coronavirus Sars-CoV-2, which causes COVID-19, during the pandemic that began in late 2019, in a specific way in each region of the world. This was because of each country's condition, employment situation, social composition (Benítes et al., 2020), as well as other demographic factors such as age distribution (Dowd et al., 2020), that affects the decision-making process. The number of cases also varies from region to region; in early August 2021, Brazil recorded 9,573.86 confirmed cases of COVID-19 per 100,000 inhabitants and 267.59 deaths due to COVID-19 per 100,000 inhabitants (WHO, 2021a). In Portugal, confirmed cases of COVID-19 per 100,000 inhabitants totaled 9,744.99 and deaths due to COVID-19 totaled 170.57 per 100,000 inhabitants (WHO, 2021b).

In the solid waste management context, some measures were found around the world, for example, the suspension of recycling programs in Brazil (Urban and Nakada, 2021) and changes in the solid waste generation profile. Many countries showed an increased generation while others showed stability in the amount of waste generated (Urban and Nakada, 2021; Zambrano-Monserrate et al. 2020). Changes in the composition of household waste generated were also noted, as reported by Aldaco et al. (2020), which indicated a 12\% increase in generation rate of organic waste in Spain during the lockdown period. Aldaco et al. (2020) also suggested that results can be deduced to the European reality and other regions with similar levels of food security.

When evaluating the management of municipal solid waste (MSW) in Brazil, in 2019, 192 million people (91\% of brazilian population) were served by the household collection service (SNIS, 2020; ABRELPE, 2020a), with a generation rate of $379 \mathrm{~kg} /$ inhab.year (ABRELPE, 2020a). The country experienced an increase of 17.9\% in the rate of MSW generation related to the last ten years, dissociated from the COVID-19 pandemic influence. There was also an increase of $30.3 \%$ in the amount of MSW destined to landfills in the same period, due to the larger population served by urban cleaning services, possibly explained by the sanction of the National Solid Waste Policy (Brasil, 2010). In the past decade, the Brazilian government imposed penalties for non-compliance with legal requirements for a good MSW management. However, 29 million tons of waste were still not being properly disposed of (ABRELPE, 2020a). During the pandemic, an increase of 15 to $25 \%$ in the household waste generation was estimated due to strategies to contain the spread of the new coronavirus, such as remote work and teaching, keeping part of the population at home for longer periods (ABRELPE, 2020b). It should be noted that among the solid waste generated in the household, there are those that have toxicity characteristics, with presence of blood or body fluids, chemical substances, and sharp materials (WHO, 2014; ANVISA, 2018). Also, many patients with various illnesses, including COVID19 , continue recovering at home, adding, therefore, a concern regarding the management of this waste, which is often collected and treated as non-hazardous waste.

In Portugal, the generation of MSW totaled 5.2 million tons in 2019, with a generation rate of 513kg/inhab.year (APA, 2020a). The generation of MSW in Portugal showed an increase of 10.8\% in 2019 compared to the generation in 2015 (APA, 2020a; APA, 2016). There is concern about the goals established by the Strategic Plan for Urban Waste 2020 (PERSU 2020), which expected a 10\% reduction in the waste generation rate per inhabitant compared to that generation in 2012 (Portugal, 2014). However, the rate achieved in 2019 was $1.13 \%$ (APA, 2020a). To meet the established targets, a 25\% reduction in the amount of MSW generated in 2020 would be necessary, a projection that, however, contradicts the growth trend observed in recent years 
(APA, 2020a). Another target present in PERSU 2020 concerns the increase of recycled MSW; for 2020, the intention was to recycle 50\% of the generated MSW (Portugal, 2014). In 2019, the recycling rate achieved 41\% of the total generated (APA, 2020).

Given the previous studies that were conducted by the research group on waste management comparison between the two countries (Mol et al, 2021), and given the moment of the COVID-19 pandemic that affected all countries in different ways, this article aims to study, carrying a literature review, the solid waste management decision-making in Brazil and Portugal during the COVID-19 pandemic, in view of the existing socioeconomic and demographic differences, and the strategy for approach to combating the health crisis between the two given countries. Once knowing the waste management approach during the COVID19 pandemic it is possible to improve the decision in possible future outbreaks.

\section{Methodology}

We carried out a literature review to identify the main scientific publications about waste management in Brazil and Portugal, focusing on the context of management measures during the COVID-19 pandemic. The survey was conducted between January and May 2021, including information that investigated the implications of the pandemic on the solid waste management in studied countries, also seeking the particular context observed in each region with similar demographic characteristics, according to the profile of countries reported by the World Bank's data. Data/reports from the government on decisions taken previously and during the pandemic were also sought. The descriptors used to access the scientific bases, PubMed and Web of Science, were: “COVID-19 waste management in South America” (OR Europe) (OR Brazil) (OR Portugal); "Demography and COVID-19 in Brazil (OR Portugal)"; "Coronavirus Pandemic and waste management in South America (OR Europe) (OR Brazil) (OR Portugal)". Few works were found in the searched databases, following the inclusion criteria adopted. Therefore, our paper is showing an important gap to be discussed in the scientific literature.

\section{Results and Discussion}

\section{Sociodemographic characteristics}

Demographic differences were identified between Portugal and Brazil (Table 1) as expected. It can be noted that the Brazilian population is predominantly younger and presents greater economic vulnerability, probably related to the degree of economic development. Also, the percentage of the Portuguese population living below the national poverty line totaled $17.2 \%$ in the same year, which takes into account the purchasing power in the country's reality (WBG, 2021d).

Table 1: Socioeconomic comparison between Brazilian and Portuguese populations.

\begin{tabular}{l|l|l|l}
\hline & $\begin{array}{l}\text { Population ages } 65 \text { and } \\
\text { above } \% \text { of total } \\
\text { population })\end{array}$ & $\begin{array}{l}\text { Poverty headcount ratio at } \\
\$ 1.90 \text { a day (2011 PPP) (\% } \\
\text { of population) }\end{array}$ & $\begin{array}{l}\text { Unemployment }(\% \text { of total } \\
\text { labor force })\end{array}$ \\
\hline Brazil & 9.3 & 4.6 & 13.7 \\
\hline
\end{tabular}


Informality and unemployment undermine the efficiency of social distancing measures, because of the existence of a significant portion of the population performing informal work activities, as highlighted by Benítez et al. (2020). This, simultaneously with the lack of direct government action, can undermine pandemic containment strategies. In 2019, in Brazil, $46.1 \%$ of the economically active population performed informal activities (IBGE, 2020).

Among the analyzed South American countries (Benítez et al., 2020), Brazil had: the highest percentage of unemployment (12\%); second lowest percentage of informal work among the urban population (38\%); second largest percentage of population below the poverty line and greater accumulation of wealth by the richest $10 \%$ of the population (42.5\%). Therefore, socioeconomic similarities between Brazil and other South American countries were perceived. Nakada and Urban (2020) describe SARS-CoV-2 contamination in the Metropolitan Region of São Paulo (RMSP) demonstrating a positive correlation between population density and number of cases, thus being a worrying factor in regions with poor infrastructure that makes social distancing impractical. In the RMSP, as described by Nakada and Urban (2020), the availability of roads and highways is related to the dissemination of COVID-19, thus demonstrating that the characteristic pendular migration in metropolitan regions is an important factor, corroborating the need to implement basic income and remote work with a view to fostering social distance.

The Latin American region has high levels of social inequality and extreme difficulty in transposing social classes (UNDP, 2021). It is noted that the crisis caused by the COVID-19 pandemic affects more strongly the countries and populations with the highest rates of poverty and social inequality. The relation between the demography and COVID-19 pandemic in Brazil was showed in Souza et al (2020) suggesting a positive association between COVID-19 diagnosis and high per-capita income but a positive association between the severe acute respiratory infection cases with unknown aetiology were associated and a lower per-capita income. In this scenario, social inequality and access to health services, food insecurity and hunger intensified in Brazil during the COVID-19 pandemic (Poblacion et al., 2021). It was high-ligthed by Ribeiro-Silva et al (2020) that for the separation of hunger and food insecurity a systematic reorganization of nutrition policies is needed. As projected by the Regional Human Development Report 2021, of the United Nations Development Program (UNDP, 2021), Latin America and the Caribbean regions presented a profile of social inequality and known pattern of economic fluctuations, facing a period of intensifying social inequality and increasing gaps between social strata in the years to come. Población et al (2021) highlights that the levels of food insecurity found in Brazil during the pandemic may reflect in the future, as good nutrition in the first years of life plays a key role in cognitive development.

Socioeconomic impacts are relevant in the context of solid waste management as they are associated with the role of recyclable material pickers, important actors in the effectiveness of the recycling system, especially in developing countries (Sarkodie e Owusu, 2020). In Brazil, the Solid Waste Policy has as one of its instruments the enforcement of waste management cooperatives and it determines that they must be integrated into decision-making processes and targeted by programs that seek their social inclusion and economic emancipation (Brasil, 2010). These data endorse the need for government action through public policies that support the class of waste pickers, and, in times of pandemic, an action aimed at increasing the rates of social isolation for these groups and reducing the occupational exposure risks, ensuring the offering satisfactory living conditions, as described in Benítez et al. (2020).

In Brazil, there was a federal income transfer policy for the unemployed population, whose monthly per capita family income did not exceed USD 96.08. The value of the benefit ranged from USD 110.33 to USD 220.67 for female heads of singleparent families, for three months (Brasil, 2020). In Portugal, support for informal and self-employed workers was listed by Council of Ministers Resolution No. 10-A/2020 (Portugal, 2020a), where self-employed workers had access to financial assistance in the amount of one third of that declared in the first quarter of 2020, if they had declared their income for at least 
three consecutive months in the last twelve months.

In Portugal, the metropolitan region of Lisbon concentrated 48\% of the country's teleworking population. In this region, in December 2020, 15.6\% of the employed population carried out their activities in telework (INE, 2021a). A concentration of jobs with a telework regime was noted in the Lisbon region, reaching 9\% of the population employed in this regime (INE, 2021a). Thus, we can see a concentration of employment opportunities in telework that favors the metropolitan region of Lisbon, giving the dynamics of social distance a geographic variable. For companies and formal workers in Portugal, a simplified lay-off was created, to maintain jobs (Portugal, 2020a). This system was classified as fundamental to respond to the period of paralysis of economic activities and covered around 800 thousand workers (Portugal, 2020b). Through the simplified lay-off system, Social Security ensured the payment of $70 \%$ of the remuneration of employees of the companies covered (Portugal, 2020a) with a progressive return of responsibility to the employer (Portugal, 2020b and Portugal, 2020c). It was noticed in the last quarter of 2020 a scenario of work underutilization of $14.1 \%$ and unemployment of $7.1 \%$ (INE, 2021b). This fact is explained, according to the National Research Institute, mostly by the adhesion to the system lay-off by companies (INE, 2021b).

\section{Municipal waste management}

The differences observed between the countries Brazil and Portugal were associated with decision-making about the functioning of economic activities and social distance. In Brazil, these were mostly taken by states and municipalities, with few decisions being taken by the federal government (Benítez et al., 2020). In Portugal, the measures associated with COVID-19 were taken by the Republic Government, in accordance with the Basic Civil Protection Law (Portugal, 2006).

This pattern was also noted in decisions regarding the operation of activities related to solid waste management. Urban and Nakada (2021) described the situation of waste management programs in thirty Brazilian cities, of which fourteen suspended their recycling programs in March 2020. An exception in the suspension of recycling was registered in the city of São Paulo, the most populous in the country, with an estimated population of 12.2 million inhabitants in 2020 (IBGE, 2021a). In this city, $79.1 \%$ of the population had a household collection service in the year 2018, which led to the collection of 3,811,785 tons of waste, part of this process is automated (Urban and Nakada, 2021).

During 2020, the city of São Paulo registered an increase of $17.4 \%$ in waste destined for selective collection, approaching 94.5 thousand tons of recyclable waste collected in 2020. This amount was 14 thousand tons higher than that recorded in 2019, being the highest value ever recorded by the city (Prefeitura de São Paulo, 2021). From March to December 2020, the initial period marked by the beginning of restrictions due to the COVID-19 pandemic in Brazil, there was a $20 \%$ increase in the total solid waste destined for selective collection, compared to the same period in 2019. The Amlurb agency, Municipal Authority for Urban Cleaning, attributes this increase to the greater consumption of recyclable packaging during the pandemic and the greater adhesion of citizens to the selective collection program, suggesting the success of the environmental education programs (Prefeitura de São Paulo, 2021; AMLURB, 2021). The example of São Paulo indicates the need for investments in the Brazilian waste management sector to guarantee the uninterrupted selection of recyclable materials in case of eventualities. This city has also recorded a smaller amount of sweeping waste since 2016, a value attributed to the decrease in public circulation and the continuity of environmental education programs (AMLURB, 2021). In Araraquara, SP, inland city of São Paulo, it was described in Ventura et al (2021) a 8\% decrease in the waste generated between January and July 2020, unlike the one found for the state capital

Another Brazilian experience refers to the city of Belo Horizonte, the capital of the state of Minas Gerais, which has an estimated population in 2020 of 2.521 million inhabitants (IBGE, 2021b), and a rate of recyclable waste generation per inhabitants of $5.98 \mathrm{~kg} /$ inhabitant.month (PBH, 2020a). In the city, 2.411 million inhabitants are served by urban solid waste 
Research, Society and Development, v. 11, n. 1, e19411124673, 2022

(CC BY 4.0) | ISSN 2525-3409 | DOI: http://dx.doi.org/10.33448/rsd-v11i1.24673

door-to-door collection and 387.719 thousand inhabitants are served by selective door-to-door collection (SNIS, 2020). The city had the suspension of selective collection activities for seven months by municipal decision (Belo Horizonte, 2020a and Belo Horizonte, 2020b). Urban and Nakada (2021) estimate losses of US \$45,589.00, 10,024 m3 of water and 1,066 m3 in landfills per month from the suspension of selective collection services in the city.

In the Federal District, where the Brazilian capital, Brasília, and the seat of the federal government is located, selective collection and solid waste sorting activities were suspended between March and May 2020, to control and contain the spread of the new coronavirus (Distrito Federal, 2020a e Distrito Federal, 2020b). The resumption of selective collection and solid waste sorting activities in the Federal District was subject to the presentation of a safety and risk prevention plan for workers (Distrito Federal, 2020b). Precarious working conditions were observed in $60 \%$ of the Waste Recovery Facilities, with no efficient lighting or ventilation as they are adapted places (PrEpidemia, 2020). There is also a variation in the number of workers due to the existence of a significant portion without a formal employment relationship (PrEpidemia, 2020).

There are differences between the municipalities and Brazilian states regarding the suspension or not of services related to selective collection, the rules adopted for its operation and the time of suspension of activities. Thus, it is noted that decentralized decisions about the functioning of the waste management sector during the pandemic make the study of changes in the dynamics of generation and treatment of waste during the pandemic in Brazil complex.

Recommendations regarding safety for the waste work activities were proposed by civil society organizations through reports by the observatory of the University of Brasília (UnB) PreEpidemia (2020), by ABRELPE (2020b) and by the Brazilian Association of Sanitary and Environmental Engineering (ABES) (ABES, 2020). These are only used as guidelines for managers. There is a consensus among the entities regarding the recommendations for the use of personal protective equipment to contain the spread of the coronavirus, and the adoption of strategies that will ensure personal distancing in work activities, while maintaining specific personal labeling standards recommendations so that waste management services can work safely for workers (PreEpidemic 2020, ABRELPE (2020b) and ABES (2020)). In ABES (2020) and PrEpidemic (2020) documents, there is still a recommendation for the removal of employees with flu-like symptoms from work activities and ABRELPE (2020) highlights the need for temporary employment to make up for possible absences.

ABRELPE (2020b) and ABES (2020) also have recommendations for increasing the frequency of backfilling waste in landfills and ABRELPE (2020b) highlights the importance of intensifying waste collection at inappropriate points, an aspect also highlighted in Portugal by the Agency Portuguese Environment (APA, 2020b).

Urban cleaning services are classified as essential (PreEpidemic 2020, ABRELPE 2020b) and ABES (2020), however, there are disagreements regarding the suspension of selective collection and recycling services. ABRELPE (2020b) suggested the maintenance of these services, contrary to what is described in ABES (2020), which also recommends the existence of assistance for those workers who have to be removed for health reasons, in line with PreEpidemia (2020). In the PreEpidemia report (2020), for the disposal of waste from households with confirmed COVID-19 positive cases, a period of 72 hours before disposal is suggested, as prescribed in the APA (2020b). It is noteworthy that the PreEpidemic report (2020) was prepared during the suspension of recycling and selective collection services in the Federal District and sought ways to enable the resumption of these activities, at which time ABRELPE (2020b) and ABES (2020) were already published.

In Portugal, services related to waste management were classified as essential services, with the Ministry of Environment and Climate Action having assigned companies and managing entities the responsibility for ensuring the continuity and uninterruptedness of the services provided (Portugal, 2020a). There was also a mapping of mass waste disposal points in the study to increase the frequency of urban cleaning services and change in disposal sites, as well as intensive action teams cleaning these points (Portugal, 2020a). 
During the pandemic, there was also the postponement of the suspension of single-use plastics in Portugal, due to the increase in demand for these products, fueled by the fear of cross-contamination (Patrício Silva et al., 2020). The incorrect disposal of protective masks used as a method of preventing contamination by Sars-CoV-2 is described in De-la-Torre et al (2021) in Peru and in other countries in South America, including Brazil. Prata et al. (2020) reports poor disposition of PPE in Portugal. Thus, it is noted that the incorrect disposition of PPE is a common problem in both countries. Filho et al (2021) showed an increasing trend in domestic waste production in 23 countries, including Portugal, during the lockdown.

In addition to the trend towards an increase in the generation of household waste during the pandemic, Filho et al (2021) highlighted an increasing tendency in consumer concern with the type of packaging used, the willingness to charge companies for the type of material used and more time spent for selective collection and forwarding for recycling. In this way, despite the trend towards an increase in waste production and the difficulties prior to the pandemic to meet the goals established in the generation of domestic waste in Portugal (APA, 2020a; PERSU, 2020), public awareness appears as a key factor for success of future goals.

The recommendations that the Government of Portugal has drafted and disseminated are formulated by the General Directorate of Health (DGS) and by the APA (Portuguese Environment Agency) which served as a basis for those linked to the solid waste management sector.

DGS (2020a) classifies the waste produced by people affected by COVID-19, as well as those arising from its treatment, as contaminated waste with associated infectious risk, also stating that they would be classified as group III (hospital waste) and indicated for treatment as such. There are also definitions of specific measures regarding the occupational health of workers involved in waste management, as well as for the removal and transport of these wastes in a hospital context, reinforcing the importance of prioritizing the waste treatment (DGS, 2020a). The key role of good management of hospital waste in reducing disease transmission was also highlighted (DGS, 2020a).

The APA also established guidelines and recommendations for waste management in the context of a pandemic (APA, 2020b), focusing on waste produced in a non-hospital context, that is, in residences, or in places with a high concentration of people, such as hotels, businesses or airports. The need was established for the waste management operating companies to ensure the minimum services, namely "in case of adoption of generalized social isolation measures", which happened. APA also advised against the waste management systems to make changes to the door-to-door collection routines, to avoid the accumulation of waste on the streets and avoid displacement of residents for longer to correctly deposit the waste, aggravating the potential for contamination (APA, 2020b). It was advised, however, that waste from selective collection should wait at least 72 hours in sorting centers before being processed (APA, 2020b and Ragazzi et al. 2020). Also in these guidelines, APA reinforced the importance of more frequent disinfection of containers, greater care in the coverage of landfills and the suspension of mechanicalbiological treatment, which depends on undifferentiated collection, to minimize the potential risk associated with waste (APA, 2020b).

Both APA and DGS (APA, 2020c and DGS, 2020b) developed a series of infographics to alert the population to the procedures to be followed in the management of waste at home, particularly in the case of homes with people affected by COVID19 or suspected of infection. In these cases, it reinforced the importance of all waste having as its final destination unsorted garbage and that it should be deposited in two bags with filling up to 2/3 of its capacity and closed, as in the case of hospital waste (APA, 2020d and DGS, 2020b). In APA (2020e) the importance is reinforced that all contaminated wastes, produced in a non-hospital context should be placed inside two resistant and well-sealed bags before being placed in containers for undifferentiated collection.

It is noted that the guidelines for the functioning of the waste management sector in Brazil have multiple sources, not 
linked to government bodies, being guidelines advised by competent bodies of civil society. The opposite happens in Portugal, where guidelines are centralized and disseminated by government agencies, which can facilitate and standardize decisions taken by those responsible for activities in the waste management sector.

Decision-making in Brazil can be considered more complex than in Portugal due to the greater territorial extension and heterogeneity of the population, both in terms of spatial distribution and demographic criteria. However, it is noted that the assessment of the Brazilian reality is made difficult by the decentralization of decision-making regarding the pandemic period. It should be noted that the lack of centralized instructions that guide unified decision-making is not unique to the waste management sector. The federation's units' decisions are reflected in other sectors, such as the official communication of confirmed cases of COVID-19, number of deaths due to the disease, and numbers of vaccinated. These demands were assumed by the Consortium of Press Vehicles due to inaccuracies in the data released by the Brazilian Ministry of Health (G1, 2020).

Therefore, lack of centralized decisions by the government made waste management decisions more difficult during the COVID-19 pandemic in Brazil, while the opposite was noted in Portugal and suggested better results as discussed. The decentralized managerial decisions increased the challenges in Brazil, making it more complex to understand the patterns and quantities of solid waste generation during the pandemic. It is necessary to continue studying the real impact on waste generation considering the management changes observed.

\section{Conclusion}

There are socioeconomic and demographic differences between the two countries, with important points linked to informality and economic vulnerability, being even more striking in the portion of the population that has worked with waste collection. Despite the increase noted in waste generation in Portugal the public awareness can be a key factor for the success in the future goals for waste management. Decision-making regarding the measures of the pandemic and the functioning of services related to waste management were centralized in Portugal and decentralized in Brazil, thus having differences in the suspension time of operation between the regions. The safety guidelines for workers in solid waste management services in Brazil were not taken by government agencies at the federal level, but by organizations representing civil society. In Portugal, there was a coalition between different public bodies, such as the work of the APA and DGS, which established the standards and guidelines that managers should follow, so that there were no ambiguous guidelines and waste management operations were similar. This decentralization in Brazil made waste management complex as well as the understanding of the pattern of waste generation. There are few references in the bases consulted, so it is necessary to continue the studies for the better understanding of COVID19 pandemic impact on waste management in the two countries.

\section{Acknowledgments}

The authors disclosed receipt of the following financial support for the research, authorship and/or publication of this article: Financial support provided by Fundação de Amparo à Pesquisa do Estado de Minas Gerais (FAPEMIG) and Conselho Nacional de Desenvolvimento Científico e Tecnológico (CNPq). Technical support was provided by Ezequiel Dias Foundation (FUNED). Also, we are grateful to Luiz Gustavo de Oliveira Schenk, for the translation and English grammar review.

\section{Authors' Contribution}

All authors contributed equally at all stages: Study design and planning; Data collection, analysis, and interpretation; Manuscript drafting and review; Approval of the final version. 


\section{References}

ABRELPE. Panorama 2020 - ABRELPE. (2020a, December). ABRELPE. Retrieved April 3, 2021, from https://abrelpe.org.br/panorama-2020/

ABRELPE. ABRELPE NO COMBATE A COVID -19 - ABRELPE. (2020b). ABRELPE. Retrieved April 3, 2021, from https://abrelpe.org.br/abrelpe-nocombate-a-covid-19/

ABES. Recomendações para gestão de resíduos em situação de pandemia por coronavírus (COVID-19). (2020, March). ABES. https://abessp.org.br/arquivos/recomendacoes_gestaoresiduos_covid19.pdf

Aldaco, R., Hoehn, D., Laso, J., Margallo, M., Ruiz-Salmón, J., Cristobal, J., Kahhat, R., Villanueva-Rey, P., Bala, A., Batlle-Bayer, L., Fullana-i-Palmer, P., Irabien, A., \& Vazquez-Rowe, I. (2020). Food waste management during the COVID-19 outbreak: a holistic climate, economic and nutritional approach. Science of The Total Environment, 742. https://doi.org/10.1016/j.scitotenv.2020.140524

AMLURB. (2021, March 18). Quantitativos. https://www.prefeitura.sp.gov.br/cidade/secretarias/subprefeituras/amlurb/index.php?p=185375

ANVISA- Agência Nacional de Vigilância Sanitária. (2018, March 28). RESOLUÇÃO DA DIRETORIA COLEGIADA - RDC no 222, DE 28 DE MARÇO DE 2018. Retrieved April 3, 2021, from https://bvsms.saude.gov.br/bvs/saudelegis/anvisa/2018/rdc0222_28_03_2018.pdf

APA - Agência Portuguesa do Ambiente. (2020a, June). Relatório anual de resíduos urbanos 2019. https://apambiente.pt/sites/default/files/_Residuos/Producao_Gest\%C3\%A3o_Residuos/Dados\%20RU/RARU\%202019.pdf

APA - Agência Portuguesa do Ambiente. (2020b). Orientações e recomendações para a gestão de resíduos em situação de pandemia por SARS-CoV-2 (COVID19). http://www.ersar.pt/pt/site-comunicacao/site-noticias/documents/orientacoes_apa_ersar_covid_v4_02092020.pdf

APA - Agência Portuguesa do Ambiente. (2020c). Emergência COVID-19 resíduos em casa - O que fazer. https://apambiente.pt/sites/default/files/_SNIAMB_A_APA/Informacao_institucional/Covid19/Covid19_ResiduosCasa.PDF

APA - Agência Portuguesa do Ambiente. (2021, July 16). Orientações para a gestão de resíduos da utilização de “testes rápidos” de diagnóstico à COVID-19. https://www.apambiente.pt/sites/default/files/_SNIAMB_A_APA/Informacao_institucional/Covid19/Orientacoes_Residuos_Testes_Rapidos_Covid19_v2.0.pdf

APA - Agência Portuguesa do Ambiente. (2016). Relatório anual de resíduos urbanos 2015. https://apambiente.pt/sites/default/files/_Residuos/Producao_Gest\%C3\%A3o_Residuos/Dados\%20RU/RARU\%202015.pdf

PBH - Prefeitura de Belo Horizonte. (2020a). Plano municipal de saneamento de Belo Horizonte 2020/2023. https://prefeitura.pbh.gov.br/sites/default/files/estrutura-de-governo/obras-e-infraestrutura/2021/_pms2020-2023_texto_completo.pdf

Belo Horizonte. (2020a, March 23). PORTARIA SLU no $35, \quad$ DE $23 \quad$ DE $\quad$ MARÇO DE 2020 http://portal6.pbh.gov.br/dom/iniciaEdicao.do?method=DetalheArtigo\&pk=1227243

Belo Horizonte. (2020b, October 19). PORTARIA SLU No $\quad$ O75, $19 \quad$ DE $\quad$ OUTUBRO DE 2020 . http://portal6.pbh.gov.br/dom/iniciaEdicao.do?method=DetalheArtigo\&pk=1235091

Benítez, M. A., Velasco, C., Sequeira, A. R., Henríquez, J., Menezes, F. M., \& Paolucci, F. (2020). Responses to COVID-19 in five Latin American countries. Health Policy and Technology, 9(4), 525-559. https://doi.org/10.1016/j.hlpt.2020.08.014

Brasil. (2010, October 2). LEI No 12.305, DE 2 DE AGOSTO DE 2010. Retrieved April 4, 2021, from http://www.planalto.gov.br/ccivil_03/_ato20072010/2010/lei/112305.htm

Brasil. (2020, April 2). LEI no $\quad$ 13.982, $\quad$ DE $\quad 2 \quad$ DE https://pesquisa.in.gov.br/imprensa/jsp/visualiza/index.jsp?data=02/04/2020\&jornal=600\&pagina=1

Cardona-Ospina, J. A., Arteaga-Livias, K., Villamil-Gómez, W. E., Pérez-Díaz, C. E., Katterine Bonilla-Aldana, D., Mondragon-Cardona, L., Solarte-Portilla, M., Martinez, E., Millan-Oñate, J., López-Medina, E., López, P., Navarro, J., Perez-Garcia, L., Mogollon-Rodriguez, E., Rodríguez-Morales, A. J., \& PanizMondolfi, A. (2020). Dengue and COVID-19, overlapping epidemics? An analysis from Colombia. Journal of Medical Virology, 93(1), 522-527. https://doi.org/10.1002/jmv.26194

Dagnino, R., \& Johansen, I. (2017). Os catadores no brasil: Características demográficas e socioeconômicas dos coletores de material reciclável, classificadores de resíduos e varredores a partir do censo demográfico de 2010. Mercado de Trabalho. Published. http://repositorio.ipea.gov.br/bitstream/11058/7819/1/bmt_62_catadores.pdf

De-la-Torre, G. E., Rakib, M. R. J., Pizarro-Ortega, C. I., \& Dioses-Salinas, D. C. (2021). Occurrence of personal protective equipment (PPE) associated with the COVID-19 pandemic along the coast of Lima, Peru. Science of The Total Environment, 774, 145774. https://doi.org/10.1016/j.scitotenv.2021.145774

Souza, W. M., Buss, L. F., Candido, D. S., Carrera, J. P., Li, S., Zarebski, A. E., Pereira, R. H. M., Prete, C. A., Souza-Santos, A. A., Parag, K. V., Belotti, M. C. T. D., Vicenti-Gonzalez, M. F., Messina, J., Sales, F. C. S., Andrade, P. S., Nascimento, V. H., Ghilardi, F., Abade, L., Gutierrez, B., . . Faria, N. R. (2020). Epidemiological and clinical characteristics of the COVID-19 epidemic in Brazil. Nature Human Behaviour, 4, 856-865. https://doi.org/10.1038/s41562-0200928-4

DGS - Direção Geral da Saúde. (2020a, March 19). Infeção por SARS-CoV-2 (COVID-19) - recolha, transporte e tratamento dos resíduos hospitalares. https://www.dgs.pt/directrizes-da-dgs/orientacoes-e-circulares-informativas/orientacao-n-0122020-de-19032020-pdf.aspx

DGS - Direção Geral da Saúde. (2020b, May 22). Gestão de resíduos. https://covid19.min-saude.pt/gestao-de-residuos/ 
Distrito Federal. (2020a, March 20). Decreto 40548 de 20/03/2020.

http://www.sinj.df.gov.br/sinj/Norma/0d2da99f97f047cfb567d3509a835e7e/Decreto_40548_20_03_2020.html

Distrito Federal. (2020b, April 14). Resolução 5 de 14/04/2020.

http://www.sinj.df.gov.br/sinj/Norma/45ad428523a5419b868cfe1e8f14a039/adasa_res_5_2020.html\#capII_art3_par1

Dowd, J. B., Andriano, L., Brazel, D. M., Rotondi, V., Block, P., Ding, X., Liu, Y., \& Mills, M. C. (2020). Demographic science aids in understanding the spread and fatality rates of COVID-19. Proceedings of the National Academy of Sciences, 117(18), 9696-9698. https://doi.org/10.1073/pnas.2004911117

Leal, W., Filho, Voronova, V., Kloga, M., Paço, A., Minhas, A., Salvia, A. L., Ferreira, C. D., \& Sivapalan, S. (2021). COVID-19 and waste production in households: A trend analysis. Science of The Total Environment, 777, 145997. https://doi.org/10.1016/j.scitotenv.2021.145997

G1. (2020, June 9). Veículos de comunicação formam parceria para dar transparência a dados de COVID-19. https://g1.globo.com/politica/noticia/2020/06/08/veiculos-de-comunicacao-formam-parceria-para-dar-transparencia-a-dados-de-covid-19.ghtml

IBGE - Instituto Brasileiro de Geografia e Estatística. (2020). Síntese de indicadores sociais uma análise das condições de vida da população brasileira. Retrieved June 17, 2021, from https://biblioteca.ibge.gov.br/visualizacao/livros/liv101760.pdf

IBGE - Instituto Brasileiro de Geografia e Estatística. (2021a). São Paulo. https://cidades.ibge.gov.br/brasil/sp/sao-paulo/panorama

IBGE - Instituto Brasileiro de Geografia e Estatística. (2021b). Belo Horizonte. https://cidades.ibge.gov.br/brasil/mg/belo-horizonte/panorama

INE - Instituto Nacional de Estatística. (2021a, April 23). No contexto da pandemia COVID-19 a Área metropolitana de Lisboa concentrou quase metade do

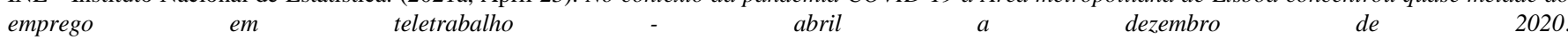
https://www.ine.pt/xportal/xmain?xpid=INE\&xpgid=ine_destaques\&DESTAQUESdest_boui=493705905\&DESTAQUESmodo=2

INE - Instituto Nacional de Estatística. (2021b, May 12). A taxa de subutilização do trabalho situou-se em 14,1\% e a taxa de desemprego em 7,1\% - 1.o trimestre de 2021. https://www.ine.pt/xportal/xmain?xpid=INE\&xpgid=ine_destaques\&DESTAQUESdest_boui=472918526\&DESTAQUESmodo=2

Mol, M. P. G., Cussiol, N. A. D. M., \& Paixão, S. (2021). Criteria for classification and destination of healthcare wastes with potential biological risk: comparison between Brazil and Portugal. International Journal of Environment and Waste Management, 27(2), 224. https://doi.org/10.1504/ijewm.2021.10034231

Nakada, L. Y. K., \& Urban, R. C. (2020). COVID-19 pandemic: environmental and social factors influencing the spread of SARS-CoV-2 in São Paulo, Brazil. Environmental Science and Pollution Research, 28(30), 40322-40328. https://doi.org/10.1007/s11356-020-10930-w

Patrício Silva, A. L., Prata, J. C., Walker, T. R., Campos, D., Duarte, A. C., Soares, A. M., Barcelò, D., \& Rocha-Santos, T. (2020). Rethinking and optimising plastic waste management under COVID-19 pandemic: Policy solutions based on redesign and reduction of single-use plastics and personal protective equipment Science of The Total Environment, 742, 140565. https://doi.org/10.1016/j.scitotenv.2020.140565

Poblacion, A., Segall-Corrêa, A. M., Cook, J., \& Taddei, J. A. D. A. C. (2021). Validity of a 2-item screening tool to identify families at risk for food insecurity in Brazil. Cadernos de Saúde Pública, 37(6). https://doi.org/10.1590/0102-311x00132320

Portugal. (2006, July 3). Lei . $^{\circ}$ 27/2006. https://dre.pt/dre/detalhe/lei/27-2006-537862

Portugal. (2014, September 18). Portaria n.o 187-A/2014. https://dre.pt/dre/analise-juridica/portaria/187-a-2014-56928479

Portugal. (2020a, March 19). Resolução do conselho de ministros n. ${ }^{o}$ 10-D/2020. Retrieved May 26, 2021, from https://dre.pt/dre/detalhe/resolucao-conselhoministros/10-d-2020-130413790

Portugal. (2020b, June 6). Resolução do conselho de ministros $n .^{o}$ 41/2020. Retrieved May 26, 2021, from https://files.dre.pt/1s/2020/06/110a00/0000200037.pdf Portugal. (2020c, December 30). Resolução do conselho de ministros . $^{o} \quad 114 / 2020$. Retrieved May 26, 2021, from https://files.dre.pt/1s/2020/12/25200/0000300006.pdf

Prata, J. C., Silva, A. L., Walker, T. R., Duarte, A. C., \& Rocha-Santos, T. (2020). COVID-19 Pandemic Repercussions on the Use and Management of Plastics. Environmental Science \& Technology, 54(13), 7760-7765. https://doi.org/10.1021/acs.est.0c02178

Prefeitura de São Paulo. (2021b, March 30). 365 dias de quarentena em São Paulo: Prefeitura analisa impacto da pandemia nos resíduos sólidos coletados na cidade. https://www.prefeitura.sp.gov.br/cidade/secretarias/subprefeituras/amlurb/noticias/?p=310489

PREpidemia. (2020). Boletins Quinzenais. Retrieved April 7, 2021, from https://www.prepidemia.org/boletins-quinzenais-prepidemia

Ragazzi, M., Rada, E. C., \& Schiavon, M. (2020). Municipal solid waste management during the SARS-COV-2 outbreak and lockdown ease: Lessons from Italy. Science of The Total Environment, 745, 141159. https://doi.org/10.1016/j.scitotenv.2020.141159

Ribeiro-Silva, R. C., Pereira, M., Campello, T., Aragão, E., Guimarães, J. M. M., Ferreira, A. J. F., Barreto, M. L., \& Santos, S. M. C. (2020). Covid-19 pandemic implications for food and nutrition security in Brazil. Ciência e Saúde Coletiva, 25(9), 3421-3430. https://doi.org/10.1590/1413-81232020259.22152020

Sarkodie, S. A., \& Owusu, P. A. (2020). Impact of COVID-19 pandemic on waste management. Environment, Development and Sustainability, 23(5), 79517960. https://doi.org/10.1007/s10668-020-00956-y

SNIS - Sistema Nacional de Informações sobre Saneamento. (2019). SNIS - Série Histórica. Retrieved April 16, 2021, from http://app4.mdr.gov.br/serieHistorica/ 
Research, Society and Development, v. 11, n. 1, e19411124673, 2022

SNIS - Sistema Nacional de Informações sobre Saneamento. (2020). SNIS - PAINEL DE INFORMAÇÕES SOBRE SANEAMENTO., from http://www.snis.gov.br/painel-informacoes-saneamento-brasil/web/painel-residuos-solidos

Urban, R. C., \& Nakada, L. Y. K. (2021). COVID-19 pandemic: Solid waste and environmental impacts in Brazil. Science of The Total Environment, 755 , 142471. https://doi.org/10.1016/j.scitotenv.2020.142471

Ventura, K. S., Morais, M. S., Vaz Filho, P., \& Brunetti Junior, A. (2021). Análise dos impactos da COVID-19 à coleta de resíduos sólidos domiciliares, recicláveis e de serviços de saúde no município de Araraquara (SP), Brasil. Engenharia Sanitária e Ambiental, 26(4), 775-784. https://doi.org/10.1590/s1413415220200309

WB - World Bank. (2021a). Population ages 65 and above (\% of total population) - Brazil | data. Retrieved June 22, 2021, from https://data.worldbank.org/indicator/SP.POP.65UP.TO.ZS?locations=BR

WB - World Bank. (2021b). Population ages 65 and above (\% of total population) - Portugal | data. Retrieved June 22, 2021, from https://data.worldbank.org/indicator/SP.POP.65UP.TO.ZS?locations=PT

WB - World Bank. (2021c). Poverty headcount ratio at \$1.90 a day (2011 PPP) (\% of population) - Brazil | data. Retrieved June 22, 2021, from https://data.worldbank.org/indicator/SI.POV.DDAY?locations=BR

WB - World Bank. (2021d). Poverty headcount ratio at $\$ 1.90$ a day (2011 PPP) (\% of population) - Portugal | data. Retrieved June 22, 2021, from https://data.worldbank.org/indicator/SI.POV.DDAY?locations=PT

WB - World Bank. (2021e). Poverty headcount ratio at national poverty lines (\% of population) - Portugal | data. Retrieved June 22, 2021, from https://data.worldbank.org/indicator/SI.POV.NAHC?locations=PT

WB - World Bank. (2021f). Unemployment, total (\% of total labor force) (modeled ILO estimate) - Brazil | data. Retrieved June 22, 2021, from https://data.worldbank.org/indicator/SL.UEM.TOTL.ZS?locations=BR

WB - World Bank. (2021g). Unemployment, total (\% of total labor force) (modeled ILO estimate) - Portugal | data. Retrieved June 22, 2021, from https://data.worldbank.org/indicator/SL.UEM.TOTL.ZS?locations=PT

WHO - World Health Organization. (2014). Safe management of wastes from health-care activities. Retrieved April 3, 2021, from https://www.euro.who.int/_data/assets/pdf_file/0012/268779/Safe-management-of-wastes-from-health-care-activities-Eng.pdf

WHO - World Health Organization. (2021a). Brazil: WHO Coronavirus Disease (COVID-19) Dashboard With Vaccination Data. WHO Coronavirus (COVID19) Dashboard With Vaccination Data. Retrieved August 18, 2021, from https://covid19.who.int/region/amro/country/br/

WHO - World Health Organization. (2021b). Portugal: WHO coronavirus disease (COVID-19) dashboard with vaccination data. WHO Coronavirus (COVID19) Dashboard With Vaccination Data. Retrieved August 18, 2021, from https://covid19.who.int/region/euro/country/pt/

Zambrano-Monserrate, M. A., Ruano, M. A., \& Sanchez-Alcalde, L. (2020). Indirect effects of COVID-19 on the environment. Science of The Total Environment, 728, 138813. https://doi.org/10.1016/j.scitotenv.2020.138813 